Marek Kurkiewicz ${ }^{1}$

Uniwersytet Kazimierza Wielkiego w Bydgoszczy

DOI: https://doi.org/10.26881/jsr.2021.16.08

\title{
ŚWIATLO WIARY. MOTYW SŁOŃCA I JEGO CHRZEŚCIJAŃSKIE KONOTACJE W POEZJI KRYSTYNY SARYUSZ-ZALESKIEJ
}

\author{
Oto Słońce wstało! Bóg twój powstał już! \\ (K. Saryusz-Zaleska, Exsurge Gloria Mea) ${ }^{2}$
}

Już niemal pół wieku temu Jerzy Kwiatkowski opublikował przekrojowe studium dotyczące symboliki solarnej w literaturze Młodej Polski, unaoczniając bogactwo tej problematyki w twórczości artystów przełomu XIX i XX w. (Kwiatkowski 1977, s. 231-325). Autor, opierając się na rozbudowanym materiale egzemplifikacyjnym, przedstawił szeroki wachlarz sposobów wykorzystywania motywu słońca; nie pominął w nim także kontekstów religijnych. Zauważył przy tym jednak, że młodopolska potrzeba transcendencji „,nie mogła znaleźć pewnego oparcia w religii oficjalnej" (Kwiatkowski 1977, s. 320), dlatego - podobnie jak w przywoływanej przez badacza słonecznej teorii mitów Friedricha Maxa Müllera i religioznawczej koncepcji Mircei Eliadego - młodopolski solaryzm ma charakter synkretyczny.

Słońce od wieków towarzyszyło kolejnym religiom (Kopaliński 1985, s. 1076-1077)3 , z jednej strony stając się niekiedy jednym z centralnych wyznaczników boskości albo jej symbolem:

Jeśli nawet w dzisiejszych czasach Słońce wydaje się nam najważniejszą gwiazdą na niebie [...], to tym bardziej dla dawnych ludów stanowiło środek i praźródło Kosmosu. Bez słońca nie ma światła ani życia. [...] Cześć oddawano bowiem nie ciału niebieskiemu, lecz wyobrażanemu pod

\footnotetext{
${ }^{1}$ drhab.mk@ukw.edu.pl,https://orcid.org/0000-0003-3843-6152

${ }^{2}$ Saryusz-Zaleska 1910, s. 156. W kolejnych cytatach nazwisko autorki zostanie zastąpione skrótem Sar-Zal.

${ }^{3}$ Odmienne zdanie prezentował Mircea Eliade (1966, s. 127), który twierdził, że choć w początkowych badaniach sądzono, iż kult słońca był znany całej ludzkości, to kolejne odkrycia zweryfikowały ten pogląd.
} 
jego postacią bóstwu. Słońce i księżyc, przez które się ono objawiało, były jedynie symbolami (Lurker 1994, s. 147).

Z drugiej strony filozofowie starożytni starali się desakralizować tę, jak pisał rumuński religioznawca, ,jedną z najpotężniejszych hierofanii kosmicznych":

Już Heraklit wiedział, że słońce ,jest co dzień nowe”. Dla Platona słońce jest obrazem dobra, które przejawia się w sferze rzeczy widzialnych [...]. Dla orfików słońce jest rozumem świata. Racjonalizacja postępuje równolegle z synkretyzmem (Eliade 1966, s. 153).

A jednak wiele wskazuje na to, że właśnie ze starożytności chrześcijaństwo przejęło kult solarny, zyskujący już w pismach wczesnochrześcijańskich sens teologiczny (Sawicka 2005, s. 65). W myśli św. Augustyna jest ono, obok Boga, jednym ze źródeł poznania (w wymiarze cielesnym). Podobnie jak Bóg, słońce istnieje, świeci i oświeca, choć tylko ten pierwszy jest „Słońcem prawdziwym”, „dawcą Światłości” (Sawicka 2005, s. 65-66). W Biblii słońce łączy się z postacią Boga przede wszystkim na zasadzie analogii ze światłem, bo choć nie ma tutaj mowy o pełnym utożsamieniu, to trudno nie dostrzegać związku między nimi. Słońce nie jest Bogiem, Bóg nie jest słońcem, co pokazuje choćby fakt, że nie zajmuje ono pierwszego miejsca w kolejności stworzenia - wraz z innymi gwiazdami powstało „dopiero” czwartego dnia (Forstner 1990, s. 93). W kolejnych partiach Pisma Świętego często mówi się o słońcu, o jego blasku, o zadaniach wyznaczonych przez Najwyższego (Forstner 1990, s. 94), odnosząc go często do postaci Chrystusa, określonego mianem „słońca sprawiedliwości” (Dogondke 2014, s. 33-47).

W Młodej Polsce, co dobitnie udokumentował i przeanalizował Jerzy Kwiatkowski, słońce stało się jednym z ważniejszych motywów (i symboli), nie tylko obecnym w pojedynczych realizacjach poetów i pisarzy, ale też wpisującym się szerzej w poszczególne programy artystyczne tych twórców. Można to zaobserwować w dorobku najbardziej znanych literatów okresu (Stanisław Wyspiański, Tadeusz Miciński, Leopold Staff), jak również tych, którym w syntezach epoki poświęca się mniej miejsca i uwagi (Józef Jedlicz, Józef Ruffer, Maryla Wolska) 4 . W tej ostatniej grupie można też wskazać na Krystynę Saryusz-Zaleską (18741945), poetkę i tłumaczkę, której dorobek w dużej mierze oscyluje wokół tema-

${ }^{4}$ Por. „Ze względu na częstotliwość odwoływania się do słońca wielu poetów zostało określonych mianem «słonecznych». Dość wspomnieć galerię poetów młodopolskich, takich jak: Antoni Lange, Józef Jedlicz, Aleksander Szczęsny, Józef Ruffer” (Lubas 1975, s. 167). 
tyki religijnej (Jakiel 2016, s. 36), a w którym poczesne miejsce zajmuje symbolika słońca ${ }^{5}$.

Już na początku odnotujmy, że nie mamy tutaj do czynienia ani z prostym utożsamieniem słońca z Boską potęgą, ani ze stałym przyporządkowaniem go którejś z Boskich postaci (Bóg, Chrystus, Maryja, Duch św.). Oczywiście nie każde przywołanie słońca wiąże się z liryczną emanacją boskości; nie zawsze gdy poetka wykorzystuje akcenty słoneczne, kontekst metafizyczny staje się wyłączny lub choćby dominujący. Wiele jest bowiem w poezji Saryusz-Zaleskiej przykładów solarnego uniwersalizmu, kiedy słońce staje się np. szeroko pojętym symbolem życia, kiedy współtworzy efektowne pejzaże (morskie, górskie, leśne), kiedy pozwala w odpowiednim świetle pokazać piękno (lub grozę) krajobrazu Włoch czy Dalmacji. Poetka łączy i zderza ze sobą, wzajemnie dopełnia i przeciwstawia sobie motywy słońca, tęczy, mgły, burzy czy chmur (Głos, Cisza słoneczna), wpisując to pierwsze w przestrzeń natury. I choć jego najczęściej eksponowanym atrybutem jest światło, blask, jasność, to poetka nie zapomina także o cieple, którym emanuje. Najlepszym tego przykładem jest wiersz $A$ to się jak nazywa?, w którym nawet niewidomi, nie mogąc w nie spojrzeć, poznają słońce po jego „ciepłym dotknięciu”.

Saryusz-Zaleska wiąże słońce ściśle $\mathrm{z}$ naturą, czego przykładem jest cykl Wirydarz w słońcu, ukazujący kwietny ogród w jego pełnym blasku. Nad morzem kolorowych kwiatów w południowym słońcu unosi się upajający zapach, a w ciszy słychać brzęczenie „złotoświecącej” pszczoły ${ }^{7}$. Przed oczami podmiotu snują się nierealne postaci, w których dostrzega „słoneczność kwiata i cichość anioła”. Wykorzystane przez poetkę rekwizyty (mistyczna lilia, tęczowa aureola) eksponują związek słońca z metafizyką. We wspomnieniach kwiaty prowokują senne wizje, pojawia się także motyw słońca kładącego „blask bogaty” na głowy bliskich, kryjącego się w spojrzeniu („oczy pełne słonecznej rozświaty”). Słońce okazuje się w tym wierszu nie tylko sprawcą wywołanych wizji:

Kiedy siądę tak w kwiatach i przymrużę oczy

I czuję ciepło słońca i zapach kwiatowy,

Powoli mi sen bije do rozgrzanej głowy...,

${ }^{5}$ To temat dotychczas nieomówiony; o jednym tylko aspekcie słownictwa i wyobraźni solarnej autorki (przy okazji pojęcia ,pryzmatu”) wspominał E. Jakiel (2016, s. 43).

${ }^{6}$ W liryku Do jubileuszowego numeru ,, Przeglądu Powszechnego” jest natomiast mowa o karmieniu ociemniałych z nędzy „,chlebem słońca świetlanym” (Sar-Zal 1910, s. 11).

${ }^{7}$ Połączenie motywów ciszy i słońca nie jest odosobnione w poezji Saryusz-Zaleskiej; podobny przykład odnajdujemy np. w wierszu Orka w słońcu, w którym pojawia się obraz „ciszy zamyślonej, promiennej od słońca” (Sar-Zal 1901, s. 39). 
ale też łącznikiem pomiędzy przeszłością a teraźniejszością, płaszczyzną spotkania z tym, co minęło:

Zda mi się rzeczywistym tylko słońce, kwiaty,

Tylko istność tu wasza, światło i spojrzenia,

Które wonie przynoszą, słońce wypromienia...

(Sar-Zal 1901, s. 47)

Dzięki upojnej woni kwiatów i słonecznemu ciepłu można obudzić „,przeszłość-bajkę", która choć na chwilę wyzwoli z szarego, powszedniego życia, przytłaczającego monotonią powtarzalności gestów i zachowań.

Nie brakuje też u Saryusz-Zaleskiej innych słonecznych (bądź tylko obecnych wspomnieniem słońca) pejzaży. Na górskich szczytach słońce przetapia sosny na „łzy żywiczne” (Duszy własnej, Sar-Zal 1910, s. 39); mówią o nim „,szczyty wniebowzięte", kiedy wstaje o poranku i wieczorem, kiedy zachodzi (Duszy własnej, Sar-Zal 1910, s. 39). Nic dziwnego, że w innym wierszu autorka pisze o „słoneczności gór”, o szczytach, które palą się jak złote pochodnie (Głos, Sar-Zal 1910, s. 41).

Motyw słońca powraca też wielokrotnie w pejzażach akwatycznych (Kurkiewicz 2008, s. 200-201), kiedy np. po morzu chodzi spersonifikowana „złocista lekka stopa słońca" (Głos, Sar-Zal 1910, s. 40); kiedy słońce, zachodząc nad morzem, kreuje nastrój leniwego bezruchu (Zatopione miasta, Sar-Zal 1910, s. 67) albo na szerokim morzu wytycza błyszczące szlaki ( $W$ porcie, Sar-Zal 1910, s. 67). Słońce bawi się młodymi falami na przybrzeżnych, wygładzonych wodą kamykach, a kiedy jedna z nich łapie roztańczony promyk, wybrzmiewa radosny śmiech. I nikt nie dostrzega, że w głębinie, mimo jasnego blasku, czai się zdradliwy cień (Zatoka jasna, Sar-Zal 1910, s. 74).

Sceny kreowane przez Saryusz-Zaleską zwykle stanowią mniej lub bardziej wyraźną refleksję quasi-filozoficzną, często natury duchowej. Przyroda odzwierciedla kondycję człowieka, jego stan emocjonalny, rozterki egzystencjalne, moralne. To, co widzi podmiot, stanowi lustrzane odbicie jego wnętrza. Tego typu zabiegami autorka wpisuje się w popularne w Młodej Polsce poetyckie realizacje konstrukcji „pejzaży wewnętrznych” (Podraza-Kwiatkowska 1994, s. 189-195). Słońce wydaje się tutaj idealnym symbolem; odwołania do obrazów wschodów i zachodów słońca, jego optymistycznego blasku i ciepła, których chwilę później brakuje (z powodu nadejścia nocy, pojawienia się chmur lub mgły), pozwalają wizualizować rozterki wewnętrzne podmiotu. Ale Saryusz-Zaleska nie rezygnuje z symboliki solarnej również wtedy, kiedy pisze o sztormach i burzach, zestawiając dzikość żywiołu ze złotą barwą słońca (Szturm, Sar-Zal 1910, s. 73) bądź kontrastując straszną noc szaleństwa natury z porankiem, kiedy nadchodzi „drżąca jutrzenka”, a śmiertelnie umęczony Chrystus „liczy trupy 
swoich dzieci” (Burza, Sar-Zal 1910, s. 77). Poetce zdarza się też łączyć w jednym tekście kilka motywów: słońce, góry, wodę, jak w wierszu Przez góry, w którym słońce odbija się w zamarzniętym górskim potoku (Sar-Zal 1910, s. 47).

W przypadku krajobrazów poetka stara się uwidaczniać szerokie spektrum symboliki słońca, jego wpływ pozytywny konfrontując z działaniem destrukcyjnym, czy też wydobywając na światło dzienne świadectwa grozy i cierpienia. Tego typu obraz przynosi liryk Bussano Vecchio, o mieście zburzonym niegdyś trzęsieniem ziemi. Południowe słońce bezlitośnie wysusza czaszki, zagląda w „wiekowe rany” (Sar-Zal 1910, s. 52), równocześnie jednak ożywia kwiaty, wnoszące na powrót życie w zniszczone katastrofą miejsce. Podobnie witalistyczny charakter ma słońce w liryku Promień po deszczu, w którym widzimy, jak w podeszczowym pejzażu rzuca się ono „,plamami złotymi” i całuje „,rozczuloną" tęczę (Sar-Zal 1910, s. 55). Inne liryki pejzażowe także nie stronią od akcentów słonecznych, tak charakterystycznych dla krajobrazów południowej Europy. Wiersz W stońcu Dalmacyi już w tytule ustala perspektywę odbioru, dając przy okazji przykład częstego w poezji Saryusz-Zaleskiej łączenia słońca z motywem zieleni, co jednoznacznie podkreśla życiodajny charakter jego siły. Słońce ,pieści” powieki i czoła, jego promienie „swawolą” (Sar-Zal 1910, s. 57) drgają, błyszczą się, mienią w przedziwny sposób, synestezyjnie intensyfikując rozlegający się śmiech dzieci. Poetka zestawia ową ziemię włoską, zamkniętą w uściskach słońca, z ziemią słowiańską, pełną chmur i mgieł. Już w tego typu konstrukcjach poetyckich pojawiają się sygnały, które można traktować jako stricte aluzje biblijne lub które przynajmniej pozwalają na tego typu skojarzenia. Wiersz Kiedy kwitna zboża eksponuje biblijny wątek ojcowskiej opieki, jaką słońce sprawuje nad zbożem (Sar-Zal 1910, s. 26), a w kolejnych wierszach tego cyklu motyw rodzicielskiej pieczy, dobrodziejstwa słońca jest konsekwentnie kontynuowany: rozświetla ono świat, towarzyszy pracy (Sad, Sar-Zal 1910, s. 27).

Symbolika ta nabiera szczególnego znaczenia w chwilach przesilenia, kiedy słońce wschodzi lub zachodzi ${ }^{8}$, tworząc na niebie urokliwą, ale też niekiedy złowrogą zorzę (Wesele krakowskie, Wieczorna pora). Poranek staje się afirmacją życia, apoteozą jasności, wesołości - „tysiącem iskier tańczy, śmieje się i skacze” (Sar-Zal 1910, s. 65) - ale kiedy wieczorem otwiera się „wielka brama słońca" (Sar-Zal 1910, s. 66), staje się symbolem transgresji, przejścia na drugą stronę, poprzez mrok nocy ku kolejnym dniom (Porzućmy wiosła). Wschodzące słońce rozdziera w strzępy mgły, odsłania piękno świata, urzeka jasnością o poranku (W stońce, Sar-Zal 1901, s. 7), a wieczorem, o „złotym” zachodzie, taką barwą lśnią piaski i tafle wody (Stawy, Sar-Zal 1901, s. 19).

${ }^{8}$ Por. „Bardzo częstą funkcją, jaką spełniają motywy solarne, jest inkrustacja obrazów przyrody. Obecność ich w tej roli jest towarzysząca, albowiem sytuacja wschodu czy zachodu słońca rzadko stanowi obraz autonomiczny” (Lubas 1975, s. 180). 
Podobnie prezentuje się sprawa jego kolorystyki, nie tylko z kluczowymi w liryce Saryusz-Zaleskiej barwami złota, srebra, błękitu, ale też z zielenią. Kiedy mowa o słońcu, wszystkie one (choć rzadko razem) konsekwentnie się pojawiają. Kolorem dominującym jest oczywiście złoto, czego świadectwa widzimy w kilkudziesięciu przypadkach, np. kiedy to oświetlane słońcem szczyty palą się ,jak pochodnie złote" (Głos, Sar-Zal 1910, s. 41); kiedy w blasku słońca liście drzew wydają się ,złotem zmaczane” (A to jak się nazywa?, Sar-Zal 1910, s. 117); kiedy słońce wypuszcza „złote groty złotych strzał” (Exsurge Gloria Mea, Sar-Zal 1910, s. 155), słońc zachody idą złote (Pożegnanie Adryatyku, Sar-Zal 1910, s. 257) albo po prostu barwa słońca określana jest jako złota (W stońce, Sar-Zal 1901, s. 7).

Poetka podkreśla tym samym królewskość słońca, jego blask i bogactwo, równocześnie nie abstrahując od popularnego wizerunku słońca, które wszak tym kolorem najczęściej się charakteryzuje ${ }^{9}$. Kiedy jednak słońce odbija swe refleksy na taflach wodnych (zwykle u Saryusz-Zaleskiej - morza), wówczas złoto zastępowane jest srebrem, czym po raz kolejny autorka odwołuje się do świadectw doświadczeń zmysłowych. Poetka nie musi w tym przypadku tworzyć abstrakcyjnych metafor i barwnych porównań, wystarczy bowiem przypomnieć sobie, jakie refleksy odbijają fale oświetlone słońcem, by zgodzić się z nią, że pierwsze skojarzenia wiążą się z odcieniem srebra ${ }^{10}$. Dlatego nie zaskakuje czytelnika ani „mgła srebrna [...] słoneczna", która wstaje z morza (Ogród, Sar-Zal 1910, s. 63), ani słońce rozpalające na morzu ,srebrzystych szlaków błyszczące koleje” ( $W$ porcie, Sar-Zal 1910, s. 70), ani „srebro fal” na tle błękitu morza (Tęsknota, Sar-Zal 1910, s. 138). Zresztą nie można tutaj nie wspomnieć, że Saryusz-Zaleska często sięga po zestawienia błękitu (morza, nieba) ze słońcem w różnych jego barwnych odmianach, o czym będziemy mieli okazję jeszcze się przekonać.

Intrygującym zestawieniem, jakiego dokonuje poetka, jest próba połączenia słońca i ciszy. W Ciszy słonecznej egzemplifikuje ją na różne sposoby: łącząc z symboliką śmierci, kiedy promienie osnuwają się po murze, rozbłyskują na ostrych kolcach młodych róż, przeglądają się w czarnych cmentarnych cyprysach; kontrastują ze złotą cichością morza, płynącymi w górze białymi chmurami;

${ }^{9} \mathrm{O}$ kolorze złotym jako silnie nacechowanym semantycznie, pojawiającym się w młodopolskiej poezji m.in. w obrazach mocno nasyconego światłem dnia, a także słońca na tle błękitów „w postaci lśniącej kuli bądź tylko rozpromienione, rzucające kaskady iskier”, wspomina Justyna Bajda (2010, s. 196-198). Badaczka pisze o przypisaniu złota do czasu letniego i krajobrazów włoskich, a to wszak spotykamy również u Saryusz-Zaleskiej.

${ }^{10}$,Woda w młodopolskiej poezji opisywana jest w kilku tonacjach: błękitnej, zielonej, czarnej oraz srebrnej” - pisze Justyna Bajda (2010, s. 200-201), dodając, że w przypadku opisu akwenów (oceanów, mórz, jezior, stawów itd.) artyści sięgali do ujęć „srebrzących się bądź złocistych od blasku słońca fal". 
dopełniają nokturnalny pejzaż, podkreślając statykę wieczoru w obrazie palącej się zorzy.

Słońce jest też jednym z podstawowych symboli światła, występujących w opozycji wobec ciemności, przy czym w tego typu przypadkach może, ale nie musi, wizualizować odwieczne dylematy religijne ${ }^{11}$. W wierszu Do jubileuszowego numeru „Przegladu Powszechnego” wrogiem rycerzy słońca jest noc, która chciałaby zniszczyć słońce; także w Rezurekcji na Wawelu pojawia się podobne przeciwstawienie. Opozycja „noc śmierci - światło życia” ukazana została na przykładzie zmartwychwstałego Chrystusa (będzie o tym mowa później), a to tylko utwierdza w przekonaniu, że analogie: słońce - światło odwołują nas do symboliki metafizycznej, z kręgu kultury chrześcijańskiej. Słońce staje się posłańcem Boga, światłem Chrystusa. Przybiera kształt złotej bramy, prowadzącej do wiekuistego szczęścia ${ }^{12}$. Bywa też traktowane jako strażnik ciemności, jak w wierszu Exsurge Gloria Mea, w którym noc drży skuta łańcuchem, a straż trzyma nad nią wiekuisty dzień, wypełniony blaskiem słońca.

Saryusz-Zaleska łączy też słońce z symboliką duszy, czym wyraźnie wchodzi na grunt topiki chrześcijańskiej - jak w rocznicowym wierszu Do jubileuszowego numeru „Przegladu Powszechnego”, z rycerzami „duchowych boi”" ${ }^{13}$ strzegącymi kryształowej fortecy, czyli miejsca, w którym „mieszka słońce”, będące „twierdzy duszą". Liryk ten stanowi pean na cześć odważnych wojowników stawiających czoła ciemności, uosabiającej wroga - zło pragnące zniszczyć słońce. Ono natomiast dodatkowo jest tutaj dawcą wiedzy: jasnej, mocnej, wytrwałej, gorącej. Łączy ze sobą wymiary: duchowy, intelektualny, fizyczny (nawet jeśli na poły metaforycznie); wszak jest tych rycerzy „zbroją”, złoci ostrza ich mieczy, kryje się w winie (albo samo nim jest), „co grzeje, krzepi, poi” (Sar-Zal 1910, s. 10). Nic dziwnego, że w wierszu jest mowa o długu, jaki rycerze zaciągają wobec słońca za jego wszelkie dobrodziejstwa.

Ponadto w wierszu tym Bóg nazwany zostaje „Panem wszystkich słońc” (Sar-Zal 1910, s. 11), co uświadamia czytelnikowi, że poetka nie utożsamia słońca z Najwyższym. Dominuje ono swoją potęgą, jest wrogiem nocy - zła, ale

${ }^{11}$, «Światło» w starotestamentowym języku obrazowym oznacza często życie w szczęściu i powodzeniu (por. Hi 18,5 n.; 21,17; Prz 13,9), w sensie nadprzyrodzonym zaś oświecenie otrzymane dzięki życzliwości i łasce Boga, Jego kierownictwo w wypełnianiu Prawa (por. Ps 27,1; 43,3; 119,105; Prz 6,23)" (Forstner 1990, s. 92).

12 Podobną symbolikę odnajdujemy w wierszu Duszy swojej - jest w nim mowa o nowym domu ,poza bramą złotą”, za ,złotem rzezaną bramą”, za „złotymi wrotami”, w których to obrazach można szukać metafor solarnych. O symbolice bramy w kontekście słońca - zob. Eliade 1966, s. 138, 146.

${ }^{13}$ Poetka używa tego słowa w znaczeniu „,bojów” (1. mn. od słowa „bój”). 
okazuje się tylko jednym z przejawów boskości Stwórcy ${ }^{14}$. Ten ostatni jest kreatorem, który powołał do życia różne słońca. Dla nas - to jedyne; dla Niego tylko jedno z wielu - słońce stanowi dowód Jego potęgi, Jego możliwości, Jego miłości do człowieka.

Oba symbole - duszy i słońca - łączy Sariusz-Zaleska w liryku Cyprysy, kolejnym konfrontującym ze sobą życie i śmierć, smutek i radość. „Czara pełna słońca" jest tutaj symbolem nacechowanym pozytywnie, wiąże się z optymizmem, szczęściem, radością, życiem. Słońce daje nadzieję tym, którzy niosą ku niemu swoje „smutne dusze”, potrafi je bowiem „przebłękitnić” (Sar-Zal 1910, s. 50). Owo powiązanie słońca i błękitu eksponuje autorka także w liryku Droga, łącząc ,pogodną słoneczność” z ,ciszą błękitową” morza ${ }^{15}$. Co jednak ciekawe, inaczej niż zwykle kolorystyka słońca zbudowana jest tutaj nie na barwie złotej, ale srebrnej, co stanowi odwołanie do refleksów mających swoje źródło w skrzących się falach (o czym była mowa wcześniej).

Jest w tym wierszu jeszcze jeden zabieg kontaminacji, funkcjonujących często osobno, motywów morza i gór. Oba pejzaże są oświetlone promieniami słońca, choć każdy w inny sposób. Z jednej strony mamy skrzące się w słońcu kryształowe góry i ich „wyiskrzone” szczyty, z drugiej właśnie owe „skry srebrne" (Sar-Zal 1910, s. 60) rozświetlające morze. To, co je łączy, to pozytywny, optymistyczny wymiar słońca, które sprawia, że ludzie, ,promienni” (niczym słońce) uśmiechem wyrażają swoje szczęście. Nic dziwnego; wszak słońce jest wszechmocnym lekarzem, który nie czekając zapłaty, potrafi skutecznie leczyć (Wezwanie, Sar-Zal 1910, s. 142).

Potęga słońca jest tak wielka, że Saryusz-Zaleska sugeruje jego podobieństwo do Boga, co najlepiej zostało wyeksponowane w Exsurge Gloria Mea z cyklu Refleksyjne ${ }^{16}$. W wierszu tym, podkreślającym fundamentalne opozycje dnia i nocy, ciemności i słońca, padają znamienne słowa: „Oto Król Twój, oto Bóg twój! Słońce!”, w których konstatujemy rzadką w swej jednoznaczności deklarację połączenia słońca i Boga, wskazującą na ich jedność. „Oto Słońce wstało!

${ }^{14}$ Perspektywa Saryusz-Zaleskiej jest w tym przypadku zgodna z tradycją: „Słońce dla autorów biblijnych jest tylko stworzeniem, jednak również oni, podziwiając i uwielbiając jego Stwórcę, wyrażają zachwyt nad jego pięknem: «Tam słońcu namiot wystawił, i ono wychodzi jak oblubieniec ze swej komnaty, weseli się jak olbrzym, co drogę przebiega» (Ps 19,6)", w: Słownik biblijny, https://biblia.wiara.pl/slownik/67ea4.Slownik-biblijny/slowo/SLONCE\#SLONCE [dostęp: 19.04.2021].

${ }^{15}$ Podobną kontaminację błękitu morza i złota słońca odnajdujemy w wizji sennej z wiersza Tesknoty. Saryusz-Zaleska obficie korzysta tutaj z palety barw: obok błękitnej ciszy morza mamy wspomniane słońce, mieniące się złotem (i bielą), jak również błękitne niebo oraz srebrne fale.

${ }^{16}$ Więcej o całym cyklu z perspektywy jego związków z biblijnymi psalmami - zob. Kurkiewicz 2008, s. 195-209. 
Bóg twój powstał już” (Sar-Zal 1910, s. 156) - podmiot powtarza, choć w nieco zmodyfikowanej formie, tę radosną wiadomość. Ten (to), już wcześniej wypuszczający „złote groty”, ,złotych strzał swych gońce”, który stanowił „zdrój orłowej siły” i ,pokój pełen mocy” (Sar-Zal 1910, s. 155), zwycięża noc, pokonuje ciemność, obejmując rządy nad światem ${ }^{17}$. Nic dziwnego, że na fali tego entuzjazmu w jednym z kolejnych wierszy cyklu jest mowa o „wieczności słońca” (Qui posuit, Sar-Zal 1910, s. 159), którego przędza osnuwa ducha. Poetka łączy ze sobą kategorie słońca, światła, wieczności, ducha i Boga. Nie pierwszy i nie ostatni raz, zdarzało jej się już bowiem pisać o „złotej chwale Pana”, która płonie na rozgorzałych wierzbach i rzuca duszę na kolana (Wstęp, Sar-Zal 1901, s. 5), określać wschód słońca jako schodzącego w ciemność posłańca Boga (Ipsa me deduxerunt, Sar-Zal 1910, s. 146) albo opisywać słońce wschodzące nad ziemią obiecaną, którego jednak nie zobaczą niewolnicy - bojący się wyzwania, cudów, laski Mojżesza i własnej duszy - nie zaryzykują oni bowiem wyzwolenia z kajdan i wędrówki w nieznane (Niewolnicy, Sar-Zal 1910, s. 133).

Bodaj najefektowniejszym manifestem solaryzmu w poezji Saryusz-Zaleskiej pozostaje wiersz o znamiennym tytule $W$ słońce, w którym pozwala ono przezwyciężyć gęste mgły i głuche czarne lasy. Wschodząc, rozdziera te mgły w strzępy, wyzwalając równocześnie (Boską) jasność świata odsłaniającego się przed oczami podmiotu:

Coraz szerzej i jaśniej!... Światło nas pochłania!

Coraz mocniej, rozgłośniej młodością bijące

Rwie się serce w tę jasność!... Pędźmy w złote słońce!...

(Sar-Zal 1901, s. 7)

Mimo braku wyraźnego nawiązania trudno nie skonstatować, że tytułowa gwiazda to nie tyle symbol panteistycznego uwielbienia poetki, ale - nawiązując do wiersza Wstep, otwierającego ten tom - świadectwo postrzegania słońca jako świetlistego atrybutu Boga. We wspomnianym Wstępie autorka pisała o słońcu jako „złotej chwale Pana"; tutaj to w tę coraz większą jasność „,rwie się serce”"18.

Analogie i kontekstualne przywołania motywu słońca Saryusz-Zaleska sytuuje także w perspektywie Chrystusa. I w tym przypadku okazuje się wierną spadkobierczynią tradycji chrześcijańskiej. Już w początkach chrześcijaństwa „słońce stało się symbolem Chrystusa, a także [...] nieśmiertelności i zmartwychwstania. W sztuce przedstawiano Chrystusa otoczonego promieniami słonecznymi” (Biedermann 2003, s. 336). W średniowieczu określano Syna Bożego

${ }^{17}$ Por. „Twe słońce nie zajdzie już więcej / i księżyc twój się nie zaćmi, / bo Pan będzie ci światłością wieczną / i skończą się dni twej żałoby” (Iz 60,20).

${ }^{18}$ Por. „O Boże mój, Panie, jesteś bardzo wielki! / Odziany we wspaniałość i majestat, / światłem okryty jak płaszczem." (Ps 104,1-2). 
mianem „prawdziwego słońca”, „zrodzonego promieniem słońca” albo „słońca ze słońca”. W pismach tego czasu prezentowano jego życie jako „misterium Słońca”; stawał się on „światłością świata”, niezwyciężonym słońcem, nieznającym zachodu, wiekuistym, rozświetlającym ludzkie umysły i serca (Sawicka 2005, s. 69-70).

Szczególnego znaczenia słońce nabiera w przełomowych chwilach życia Jezusa, dlatego motyw ten powraca przy okazji wierszy „świątecznych”. Już Wigilia Bożego Narodzenia daje okazję objawienia Boskiej światłości. Saryusz-Zaleska buduje opozycję długiej nocy, którą zakończy dzień Boży „chwałą wezbrany światła" (Wigilia, Sar-Zal 1910, s. 22) ${ }^{19}$. W radosny świąteczny poranek oczy pacholęcia otwierają się bowiem ,na słońce” i rodzi się jasny, płomienny, świąteczny dzień. Owo powiązanie słońca z boskością nie budzi w tym wierszu wątpliwości. Olbrzymie, mocne i pełne życia płomieniste słońce spływa „łunami mocy” (Sar-Zal 1910, s. 22), w spektakularny sposób głosząc chwałę Pana. Maluchna Dziecina mocą swojego głosu potrafi, mimo mrozu, przywracać ziemi życie, przywołując posłuszne mu słońce, tym bardziej że w jego malutkim serduszku jest żar „stu słońc”, zdolnych przetopić tę ziemię w „ognistą łzę” (Nad biela nocy mroźnej stanęta śmierci głusza ..., Sar-Zal 1910, s. 177).

Nie mniej istotnego znaczenia nabiera słońce w perspektywie zmartwychwstania i późniejszych wydarzeń ${ }^{20}$. Ukrzyżowany wraca wśród świetlnych, słonecznych, refleksów (Zmartwychwstanie, Sar-Zal 1910, s. 198-199), szczyty górskie palą się uwielbieniem, złota i blasku słońca nie mąci żaden cień. Przez „ciszę słoneczną", jak głos ze snu, dźwięczy zapowiedź powrotu „na wieki” (Roztworzone nad światem sq upusty chwaty ..., Sar-Zal 1910, s. 201) 21.

Najciekawsza z naszej perspektywy jest jednak zapowiedź, że „w błysku wszechmocnej woli” zmartwychwstanie „Bogiem słonecznym ludów”. Saryusz-Zaleska wpisuje zatem Chrystusa w poczet bóstw solarnych (Na rozstajnych drogach Go ukrzyżowali ..., Sar-Zal 1910, s. 192). Podobnie „świetlisty” jest Syn Boży w Rezurekcji na Wawelu. Konstatujemy tutaj opozycję „,noc śmierci-światło życia" właśnie na przykładzie zmartwychwstałego Chrystusa. Jest mowa o „nowego światła chrzcie”, o grobie czarnym przeciwstawionym jasnemu dniu, o spływającej pod stopy „światłości ulewie” (Sar-Zal 1910, s. 13-14), wreszcie o światłości samego Syna Bożego, która przegania śmierć. Saryusz-Zaleska

${ }^{19}$ Por. „W tajemnicy Bożego Narodzenia Chrystus przychodzi wśród ciemności tego świata jako nowe słońce - sol novus, zwiastujące nowy dzień" (Sawicka 2005, s. 72).

${ }^{20}$ Por. Sawicka 2005, s. 72-74.

${ }^{21}$ Eliade, nawiązując do różnych kultur i wierzeń, pisał o słońcu, że jest ono prototypem tego, który zmartwychwstaje, w nim upatrując inspiracji dla twórców kolejnych religii: „Dzięki wtajemniczeniu człowiek staje się niejako synem istoty najwyższej, a raczej staje się nim na nowo dzięki rytualnej śmierci, po której następuje jego zmartwychwstanie jako słońce" (Eliade 1966, s. 138). 
konsekwentnie wiąże potęgę Jezusa z mocą jego światłości i blasku. W Świątyni Twojej petnej chwały Twojej... (Sar-Zal 1901, s. 69) ,pożary rozświtu” obejmują łuną miejsca święte; złocone łuki, sklepienia z błękitu toną w złotej mgle. Z tej ostatniej wyłania się gorejący krzyż, na którym bieleje święte ciało Chrystusa ${ }^{22}$. Lud, olśniony płynącą z góry światłością, może tylko nieśmiało próbować podnieść wzrok ${ }^{23}$.

Poetka nierzadko czyni też słońce symbolem Maryi Panny, co nie tylko jest ściśle powiązane $\mathrm{z}$ aspektem chrystologicznym, lecz także stanowi świadectwo łączenia pierwiastków maryjnych i solarnych. W średniowiecznych pismach Matka Boska bywa nazywana ,jasnym słońcem”, „słońcem błyszczącym”, „słońcem jaśniejącej chwały” itp. (Sawicka 2005, s. 82) Porównanie do słońca wyraża cześć dla jej cielesnego i duchowego dziewictwa, czystości słonecznego blasku i światła. Równocześnie jest „rodzicielką słońca wiecznego”, „matką Słońca”, czyli Chrystusa (Sawicka 2005, s. 84). Maryjny aspekt solaryzmu poetki najplastyczniej zostaje zaprezentowany w kolejnych wierszach z cyklu $A d$ te levavi oculos meos, o którym Wojciech Gutowski pisał, że jest on świadectwem chrystologii właśnie o orientacji maryjnej (Gutowski 2001, s. 144). Już w pierwszym z tekstów, o znamiennym tytule Boga rodzica, natrafiamy na następujący fragment:
Bogu Twój kwiat rozkwita!
W światłości słońc ukryta,
Wyjdź ku nam z słońca bram,
Maryja! Maryja!
(Sar-Zal 1910, s. 163)

Saryusz-Zaleska po raz kolejny wykorzystuje tutaj motyw słońca - bramy, przy czym tym razem połączony ze świętością Maryi, skrywającej się jeszcze

${ }^{22}$ Saryusz-Zaleska, nawet ukazując motyw Ukrzyżowania na pozór w duchu dekadentyzmu, w gruncie rzeczy nie odbierała cierpieniu Chrystusa wyjątkowego znaczenia. W liryku Krzyż na stepie, przywołującym na myśl słynną Próżnię Stanisława Korab-Brzozowskiego, pojawia się wprawdzie krzyż, który milcząc poczerniałe wyciąga ramiona, ,złoty blask zachodu" nie zwiastuje zmartwychwstania, tylko ginie w mroku, a z ciała wiszącego na krzyżu pada cien - a jednak jest to cień błękitny, który niesie odpoczynek, ukojenie. Czarny krzyż jest drogowskazem „na pustym bezdrożu pośród chaosu i grozy świata". Ostatecznie więc Krzyż na stepie stanowi polemikę z głośnym wierszem młodopolskiego samobójcy.

${ }^{23}$ Biel i światło, które biją od Chrystusa, mogą przywoływać na myśl scenę Przemienienia na górze Tabor: „Po sześciu dniach Jezus wziął z sobą Piotra, Jakuba i brata jego Jana i zaprowadził ich na górę wysoką, osobno. Tam przemienił się wobec nich: twarz Jego zajaśniała jak słońce, odzienie zaś stało się białe jak światło" (Mt 17,1-2). 
w blasku Pana, z niego biorącej swoje źródło ${ }^{24}$. Ten blask można też dostrzec w słonecznej plamie, która widnieje w miejscu, gdzie - zanim odszedł - stał Boski posłaniec przynoszący Pannie wieść o zwiastowaniu (I odszed t od niej aniot..., Sar-Zal 1910, s. 168). Poetka w następnych wierszach cyklu konsekwentnie stosuje tę analogię, czego dowodem jest choćby tekst Więc ustyszawszy owa wieść w rodzinnym mieście..., w którym słońce kryje w sobie blask „utajonej tęczy” (Sar-Zal 1910, s. 170), a sama Maryja tuli do stóp blaski „wschodzącego” w niej, milczącego Boga (Sar-Zal 1910, s. 171). Słońce towarzyszy też obrazom Świętej Rodziny (Nad domek Nazareński Anieli przynieśli...): kiedy Józef pracuje, szmaragdowo-złotym potokiem rozlewa się ono pod drzewkami oliwnymi; w słońcu pasą się stada owiec, a temu wszystkiemu przyglądają się Maryja i Jezus (Sar-Zal 1910, s. 186).

Szczególnego znaczenia nabierają jednak połączenia symboliki słońca z postacią Matki Boskiej w obrazach jej wniebowzięcia. Poeci średniowiecza porównywali Maryję do wspaniałego słońca wschodzącego na duchowym niebie Kościoła; królowała niczym słońce na nieboskłonie, obleczona w światłość słoneczną, przyozdobiona koroną z dwunastu gwiazd (Sawicka 2005, s. 89-90). Także u Saryusz-Zaleskiej skronie Maryi zdobi wówczas złota korona z gwiazd (Wniebowzięcie, Sar-Zal 1910, s. 203) ${ }^{25}$, podobnie jak w pochodzącym z pieśni Matko niebieskiego Pana ${ }^{26}$ motcie z wiersza Królowej:

Jak bogata z słońca szata,

$\mathrm{Z}$ gwiazd Korona upleciona

Na głowie.

(Sar-Zal 1910, s. 205)

Maryja nazywana jest w tym utworze „Panią słońca”, jej tron ustawiony jest w „przybytku słońca”, które ściele się u jej nóg „tęczą i blaskiem i ciepłością złotą”. W ujęciu podmiotu jest ona „słonecznym promieniem złocona” i w słońcu „utwierdzona”. Słońce nabiera tutaj zresztą atrybutów boskich (,słońce łaski”, „słońce boże”), rwie się ku niemu życie, jego blask spływa na kwiatowe gaje

${ }^{24}$ Obraz Maryi jako „bramy słońca wschodzącego” pojawia się już w średniowiecznej poezji liturgicznej (Sawicka 2005, s. 84).

${ }^{25}$ Zob.: „Już teologowie w czasach karolińskich widzieli w odzianej w słońce kobiecie z księżycem pod stopami zarówno Maryję, jak i Kościół. [...] Wraz z szerzącą się od XII wieku interpretacją maryjną słońce, księżyc i wieniec z dwunastu gwiazd stają się kosmicznymi parabolami pięknej dziewicy" (Lurker 1994, s. 143).

${ }^{26}$ Zob. Śpiewnik kościelny, https://pl.wikisource.org/wiki/ Śpiewnik_kościelny/Matko_niebieskiego_Pana [dostęp: 12.04.2021]. 
i ogrzewa ziemię (P, s. 205). Trudno zatem w tym czerpiącym z tradycji obrazie oddzielić symbolikę solarną od boskich wcieleń i ich związku z naturą ${ }^{27}$.

Podsumowując: w poezji Krystyny Saryusz-Zaleskiej słońce nie zawsze niesie ze sobą kontekst metafizyczny. Nierzadko bywa jednym z posłańców Boga, świadectwem Jego potęgi i mądrości. Wszak Bóg jest „Panem wszystkich słońc”, a zatem to świecące nam okazuje się tylko jednym z wielu, o które w swej mądrości Stwórca zadbał, by człowiek mógł żyć w doczesnym świecie i zasłużyć sobie na życie wieczne. Mimo swej potęgi słońce w poezji Saryusz-Zaleskiej „pozostaje jednak zawsze tylko parabolą, obrazem, symbolem przewyższającej wszystko wielkości Boga” (Lurker 1994, s. 149). Wiąże się też z postacią Chrystusa $\mathrm{i}$ - wbrew pesymistycznym, dekadenckim poglądom niektórych poetów służy jego „rozjaśnieniu”, uczłowieczeniu, bez pokusy laicyzacji (por. Kwiatkowski 1977, s. 298).

A zatem można powiedzieć, że autorka nie tyle proponuje nowe ujęcie problemu, ile płynnie wpisuje się w niektóre młodopolskie tendencje przedstawiania topiki solarnej, opisane w fundamentalnej pracy Jerzego Kwiatkowskiego. Brakuje w jej poezji katastroficznych ujęć słońca, tonacji grozy czy odbicia pesymistyczno-kryzysowych nastrojów epoki, to bowiem raczej jasna, „majorowa” odsłona tematyki; słońce zdecydowanie częściej bywa opiekuńcze niż niebezpieczne, przyjazne niż groźne. Słońce to symbol ziemskiego życia i równocześnie złota brama, przez którą człowiek może się dostać do Boga.

\section{Bibliografia}

Bajda J. (2010), „,Poeci - to są słów malarze...”. Typy relacji między stowem a obrazem w ksiażkach poetyckich okresu Młodej Polski, Wrocław.

Biblia Tysiaclecia. Pismo Święte Starego i Nowego Testamentu, https://biblia. deon.pl.

Biedermann H. (2003), Leksykon symboli, przeł. J. Rubinowicz, Warszawa.

Dogondke D. (2014), Interpretacja mesjańska wyrażenia ,stońce sprawiedliwości” (Ml 3,20), „Verbum Vitae” nr 26.

Eliade M. (1966), Traktat o historii religii, przeł. J. Wierusz-Kowalski, Warszawa.

Forstner D. (1990), Świat symboliki chrześcijańskiej, przeł. W. Zakrzewska $\mathrm{i}$ in., Warszawa.

${ }^{27} \mathrm{O}$ maryjnym aspekcie poezji Saryusz-Zaleskiej, na przykładzie cyklu Ad Te levavi oculos meos, pisał Edward Jakiel (2010, s. 319-329), który nie wspominał jednak o jego akcentach solarnych. 
Gutowski W. (2001), Z próżni nieba ku religii życia. Motywy chrześcijańskie w literaturze Młodej Polski, Kraków.

Jakiel E. (2010), W stużbie katechezy: teksty literackie w periodykach religijnych 1890-1918 w kontekście Młodej Polski, Gdańsk.

Jakiel E. (2016), Motta biblijne w poezji Krystyny Saryusz-Zaleskiej, „Język Szkoła - Religia" t. 11, nr 1.

Kopaliński W. (1985), Stownik mitów i tradycji kultury, Warszawa.

Kurkiewicz M. (2008), „A teraz czas, by uspokoić ducha...” - Krystyny Saryusz-Zaleskiej poszukiwania Boga (o cyklu „,Refleksyjne”), w: Poszukiwanie świadectw. Szkice o problematyce religijnej w literaturze II połowy XIX i poczatku XX wieku, red. J.A. Malik, Lublin.

Kwiatkowski J. (1977), Od katastrofizmu solarnego do synów słońca, w: Młodopolski świat wyobraźni. Studia i eseje, red. M. Podraza-Kwiatkowska, Kraków.

Lubas R. (1975), Motywy słońca w poezji ,nieawangardowej” Krakowa lat międzywojennych, „Rocz. Nauk-Dydakt. Pr. Hist. Lit. WSP Kraków”, z. 6 (56).

Lurker M. (1994), Przesłanie symboli w mitach, kulturach i religiach, przeł. R. Wojnakowski, Kraków.

Podraza-Kwiatkowska M. (1994), Symbolizm i symbolika w poezji Młodej Polski, Kraków.

[Sar-Zal] Saryusz-Zaleska K. (1901), Pejzaże: Pustowarnia i Kraków, Kraków.

[Sar-Zal] Saryusz-Zaleska K. (1910), Poezye, Kraków.

Sawicka J. (2005), Symbolika solarna w średniowiecznej poezji liturgicznej, „Pamiętnik Literacki” nr 2.

Stownik biblijny, https://biblia.wiara.pl/slownik/67ea4.Slownik-biblijny/ slowo/SLONCE\#SLONCE.

Śpiewnik kościelny (1838), red. M.M. Mioduszewski, Kraków, https://pl. wikisource.org/wiki/Śpiewnik_kościelny /Matko_niebieskiego_Pana.

\section{Streszczenie \\ Światło wiary. Motyw słońca i jego chrześcijańskie konotacje w poezji Krystyny Saryusz-Zaleskiej}

Artykuł przynosi omówienie sposobu funkcjonowania motywu słońca w poezji Krystyny Saryusz-Zaleskiej (1874-1945). Na gruncie twórczości poetyckiej młodopolskiej autorki nie mamy do czynienia ani z prostym utożsamieniem słońca z Boską potęgą, ani ze stałym przyporządkowaniem go którejś z Boskich postaci (Bóg, Chrystus, Maryja). Nie każde przywołanie słońca wiąże się z liryczną emanacją boskości; nie zawsze kiedy poetka wykorzystuje akcenty słoneczne, kontekst metafizyczny jest wyłączny lub choćby dominujący. Wiele jest 
bowiem w poezji Saryusz-Zaleskiej przykładów solarnego uniwersalizmu, kiedy słońce staje się symbolem życia, kiedy współtworzy efektowne pejzaże (morskie, górskie), kiedy pozwala w odpowiednim świetle pokazać piękno krajobrazu Włoch czy Dalmacji. Równocześnie jednak nie można mówić o trwałej sekularyzacji tego motywu, mimo wszystko bowiem wątki religijne bardzo często łączą się ze słońcem.

Słowa kluczowe: Krystyna Saryusz-Zaleska, Młoda Polska, religia chrześcijańska, słońce, symbolika

Summary

The light of faith. The motif of the sun and its Christian connotations in the poetry of Krystyna Saryusz-Zaleska

The paper discusses the way the motif of the sun functions in the poetry of Krystyna Saryusz-Zaleska (1874-1945). Basing upon the poetry of the author from the Young Poland epoch, we are dealing neither with a simple identification of the sun with divine power, nor with a permanent assignment of it to one of the divine figures (God, Christ, Mary). Not every instance of invoking the sun is associated with a lyrical emanation of divinity; and not always when the when the poet uses solar accents, the metaphysical context is exclusive or even dominant. There are many examples of solar universalism in Saryusz-Zaleska's poetry, when the sun becomes a symbol of life, when it co-creates spectacular landscapes (sea, mountain), when it allows for the demonstration of the beauty of the Italian or Dalmatian landscape in proper lighting. At the same time, however, there is no mention of a permanent secularization of this motif, because, after all, religious accents are very often connected with the sun.

Keywords: Krystyna Saryusz-Zaleska, Young Poland, Christian religion, sun, symbols 